Migration Studies - Review of Polish Diaspora nr 4 (174)/2019, http://www.ejournals.eu/Studia-Migracyjne/ DOI: $10.4467 / 25444972$ SMPP.19.044.11358

\title{
Autonomia kobiet w kontekście migracyjnym. Rozważania na przykładzie polskich migrantek w Norwegii
}

\author{
KATARZYNA GMAJ'
}

Uczelnia Łazarskiego

\begin{abstract}
Celem artykułu jest przedstawienie strategii badawczej, którą warto zastosować, starając się lepiej zrozumieć obecność Polek w Norwegii. Ich napływ do Norwegii i późniejsze ścieżki migracyjne w dużym stopniu kształtował nieformalny charakter podejmowanych prac. Polki korzystały też z w pełni sformalizowanych możliwości przyjazdu. Dynamiczny wzrost liczby polskich migrantów rozpoczął się po 2004 roku. Wciąż obserwujemy dysproporcję między liczbą mężczyzn i kobiet. Tych ostatnich jest mniej, ale są lepiej wykształcone.

Analizowanie migracji jedynie z perspektywy ekonomicznej motywacji, nie oddaje bardziej złożonego charakteru zjawiska. Migracje Polek można lepiej zrozumieć, odwołując się do perspektywy biograficznej i używając pojęć, takich jak pragnienia, aspiracja i autonomia. W artykule wykorzystałam materiał z własnych badań, zebrany podczas pobytów w Norwegii jako visiting researcher na Oslo Metropolitan University (dawniej Oslo and Akershus University College of Applied Sciences) oraz projektu Transfam. Przeanalizowałam wywiady z kobietami, które do pracy za granicę wyjechały samodzielnie. Poszczególnym fazom biografii przypisane zostały odpowiadające im pragnienia, aspiracje, proces podejmowania decyzji oraz sposób realizacji pragnień.
\end{abstract}

Słowa kluczowe: polskie migrantki, pragnienie, aspiracje, autonomia, Norwegia

\section{The Autonomy of Women in the Migratory Context. Reflections on the Example of Polish Migrant Women in Norway}

The article aims at presenting a research strategy that provides a better understanding of the presence of Polish females in Norway. A significant part of female migrants' inflow as well as their strategies and career paths have been shaped by an irregular and undocumented character of work. However, other Polish women have legalized their stay using family reunification procedures,

\footnotetext{
1 Kontakt: k.gmaj@lazarski.edu.pl
} 
recruitment agencies or other channels providing legal employment. The rapid increase in the number of Polish migrants in Norway was evident after 2004. Although female migrants are lees numerous than male ones, they are better educated.

An investigation that is limited to economic motivations does not reflect the more complex nature of their mobility. Using a conceptual framework of desire, aspiration and autonomy, together with a biographical approach, seems to be more fruitful. The author analyses interviews with women who started their international mobility on their own. Phases of a biography are related to corresponding desires, aspirations, decision-making processes and a way of fulfilling or transforming an initial desire. The article is based on Transfam research and material gathered by the author during her visits as a visiting researcher at Oslo Metropolitan University (former Oslo and Akershus University College of Applied Sciences).

Key words: Polish female migrants, desire, aspiration, autonomy, Norway

\section{Wprowadzenie}

Poniższy artykuł jest odzwierciedleniem kierunku refleksji związanej z obserwowaniem Polaków w Norwegii². Doszłam do wniosku, że analizowanie tej migracji jedynie z perspektywy ekonomicznej motywacji nie oddaje bardziej złożonego charakteru zjawiska. W szczególności migracje Polek do Norwegii można lepiej zrozumieć używając pojęć, takich jak pragnienia, aspiracja i autonomia. Analiza przedstawiona w tekście nie wyczerpuje problematyki autonomii polskich migrantek. Pokazuje natomiast strategię badawczą, którą warto zastosować, starając się lepiej zrozumieć obecność Polek w Norwegii.

Artykuł wpisuje się w dyskusję na temat feminizacji migracji, która z jednej strony odnosi się do wzrostu udziału kobiet w migracjach, a z drugiej do zmieniającego się charakteru migracji kobiet, które coraz częściej są autonomicznymi migracjami, a w mniejszym stopniu migracjami członków rodziny, pozostających na utrzymaniu mężczyzn (Slany i in. 2010). W dyskusji na temat feminizacji migracji coraz częściej przywoływane są źródła historyczne, które nie ograniczają się jedynie do dwudziestego wieku; wskazujące, że kobiety przez wieki stanowiły istotną część przepływów migracyjnych, a strukturę migrantów pod względem płci kształtowały regionalne rynki pracy oraz lokalne przekonania w krajach wysyłających (Donato i Gabaccia 2015).

2 Najpierw w ramach projektu Transfam - Doing Family in a Transnational Context - prowadzonego przez konsorcjum składające się z Uniwersytetu Jagiellońskiego (lider) i partnerów: Centrum Stosunków Międzynarodowych, Agder Research, NOVA Oslo i Akershus University College of Applied Sciences. Projekt był finansowany z funduszy norweskich, w ramach programu Polsko-Norweska Współpraca Badawcza realizowanego przez Narodowe Centrum Badań i Rozwoju w ramach Norweskiego Mechanizmu Finansowego na lata 2009-2014, kontrakt nr Pol-Nor/197905/4/2013. Na temat projektu można więcej przeczytać na stronie: www.transfam.socjologia.uj.edu.pl. Byłam liderem zadania 6. Strategie osiedlania się w Norwegii. Ponad to, trzykrotnie - latem 2016, 2017 i 2018 roku - byłam visiting researcher na Oslo Metropolitan University (wcześniej Oslo and Akershus University College of Applied Sciences). 


\section{SM̂PP}

\section{Formowanie się polskiej społeczności w Norwegii}

Chociaż pojedynczy Polacy osiedlali się w Norwegii jeszcze w dziewiętnastym wieku, to za początek polskiej społeczności w Norwegii uznać można migrację kilku tysięcy polskich uchodźców politycznych w latach 80. dwudziestego wieku. Lata 90. dwudziestego wieku to okres napływu pracowników sezonowych, przybywających na podstawie dwustronnych umów o tymczasowej pracy w rolnictwie. Liczba polskich migrantów rosła dynamicznie po 2004 roku (Gmaj 2018a, 2018b, Iglicka i in. 2018). Obecnie Polacy stanowią największą grupę imigrancką w Norwegii, liczącą według oficjalnych norweskich statystyk około 98691 (początek 2019 roku) z dodatkowymi 13294 osobami urodzonymi w Norwegii, a mającymi polskich rodziców i 6063 jednego polskiego rodzica (Statistics Norway)3. Starając się przybliżyć do rzeczywistej liczby Polaków trzeba jeszcze uwzględnić około 30 000-40 000 pracowników przebywających w Norwegii przez okres krótszy niż sześć miesięcy w roku, którzy są zarejestrowani jako osoby niebędące rezydentami. Dodać też trzeba osoby, które oficjalnie przebywają w celach turystycznych, ale podejmują nierejestrowaną pracę. Jako obywatele Unii Europejskiej (UE) nie potrzebują wiz, dlatego określenie ich liczby jest bardzo ryzykowne.

Bez względów na początkowy cel przybycia do Norwegii, pobyt części Polaków przedłuża się i staje się długoterminowy. Znaczna część z nich sprowadza dzieci z Polski lub zakłada rodziny już w Norwegii. Osiedlając się, radykalnie zmieniają swój tryb życia (Bell i Erdal 2015, Gmaj 2018a, 2018b, Gmaj i Iglicka 2018, Iglicka i in. 2018).

Napływ Polek do Norwegii i ich późniejsze ścieżki migracyjne przed wstąpieniem Polski do UE w dużym stopniu, podobnie jak w innych krajach europejskich, kształtował nieformalny charakter podejmowanych przez nie prac. Wiązało się to z często niestabilnym i niskopłatnym zatrudnieniem w usługach opiekuńczych i sprzątaniu w prywatnych gospodarstwach domowych (Main, Czerniejewska 2017). Nadreprezentacja Polek pracujących przy sprzątaniu utrzymuje się także po wstąpieniu Polski do UE. Należy jednak podkreślić, że stanowią one bardzo zróżnicowaną pod względem wykształcenia i kapitału społecznego kategorię pracowników (Erdal 2014, Friebierg 2010). Oczywiście część kobiet korzystała z w pełni sformalizowanych możliwości przyjazdu, np. na podstawie łączenia rodzin czy podjęcia zarejestrowanej pracy. Warto wspomnieć przypadek pielęgniarek, które sprowadzane były z Polski w latach 2001-2004 za pośrednictwem agencji pracy, na podstawie specjalnego programu. Zainteresowanie Polek tą propozycją było jednak znacznie mniejsze niż zakładali Norwegowie. Wyemigrowało zaledwie 190 kobiet (Napierała 2010: 116).

Biorąc pod uwagę geograficzne rozproszenie, ponad połowa Polaków mieszka w czterech hrabstwach (Oslo, Akershus, Rogeland, Hordaland). Reszta zamieszkuje

${ }^{3}$ Do tego doliczyć można jeszcze 2551 osób urodzonych w Norwegii, które mają przynajmniej jednego polskiego dziadka oraz 302 osoby urodzone poza Norwegią, których jeden z rodziców pochodzi z Polski, a drugi jest urodzony w Norwegii. 
pozostałe terytorium kraju, a naszych rodaków odnaleźć można nawet w niewielkich miejscowościach. W strukturze społeczno-demograficznej najbardziej uderza dysproporcja pomiędzy liczbą kobiet i mężczyzn. Częściowo może ją tłumaczyć to, że do 2009 r. Norwegia utrzymywała ograniczenia dla migrantów zarobkowych pochodzących z nowych państw członkowskich UE. Aby uzyskać zezwolenie na pobyt, musieli mieć pracę w pełnym wymiarze czasowym, z wynagrodzeniem takim, jak norwescy pracownicy. Takie wymogi mogły zniechęcić kobiety, ponieważ trudniej było je spełnić w sektorze przez nie zdominowanym, czyli w sprzątaniu (Friberg i in. 2012). Niemniej jednak, nawet po zniesieniu tych ograniczeń, rozbieżność w proporcjach płci utrzymuje się nadal, chociaż coraz więcej kobiet jest zarejestrowanych jako rezydenci. Prawdopodobnie związane jest to z zapotrzebowaniem na pracowników w tzw. męskim sektorze pracy. Warto wspomnieć, że norweski rynek pracy charakteryzuje jeden z najwyższych w Europie poziomów segregacji ze względu na płeć, np. sektor ochrony zdrowia zdominowany jest przez kobiety, a budownictwo przez mężczyzn (Baba, Dahl-Jørgensen 2010).

Przekrój zawodowy Polaków mieszkających w Norwegii w dużym stopniu odzwierciedla popyt na siłę roboczą. Polacy zatrudnieni są głównie w następujących sektorach gospodarki (1) budownictwo, energia elektryczna, zaopatrzenie w wodę, kanalizacja, gospodarka odpadami; (2) produkcja; (3) rekrutacja pracowników i zapewnienie personelu4 ${ }^{4}$. Biorąc pod uwagę strukturę wykształcenia, w 2018 roku, około połowa (48 proc.) polskich migrantów miało wykształcenie średnie, a prawie 1/3 wyższe (zawodowe 16 proc. i magisterskie 16 proc.) $)^{5}$. Kobiety są lepiej wykształcone niż mężczyźni. Dane z roku 2012 pokazują, że wyższe wykształcenie posiadało 52 proc. kobiet i tylko 23 proc. mężczyzn (Steinkellner 2015: 36).

\section{Zastosowanie pojęć pragnienia, aspiracje i autonomia w analizie migracji kobiet}

Uwzględniając fakt, że kobiety osadzone są w codziennych relacjach społecznych, autonomia rozumiana jest w artykule jako zdolność do dokonywania wyborów dotyczących własnego życia i podejmowania działań w celu realizacji pragnień (Bastia 2013). W kontekście migracyjnym, ale oczywiście nie tylko, wymaga to dokonywania refleksji nad własnym położeniem, oceny różnych opcji, krytycznego ich przeanalizowania,

${ }^{4}$ Segmentacja rynku pracy i popyt na pracę w poszczególnych sektorach gospodarki mogą być analizowane pod kątem zmian społecznych i strukturalnych obserwowanych na norweskim rynku pracy. Restrukturyzacja sektorów pracochłonnych, takich jak budownictwo oraz uelastycznienie stosunków pracy, tendencja do zatrudniania czasowych zamiast stałych pracowników oraz ich powiązania z migracją międzynarodową są opisane w literaturze (n.p. Sassen 2005, Haakestad, Friberg 2017).

5 Patrz. Tabela 4. Level of education for immigrants 16 years and older. Country background. Num- 


\section{SM̂PP}

wynegocjowania strategii i podjęcia działań, czyli przejęcia pewnej kontroli nad własnym życiem (Bastia 2013, Hirschmann 2003). Jak zauważa Tanja Bastia zastosowanie tego pojęcia w analizach migracji uwzględniać powinno to, że autonomię traktować można jako cel sam w sobie lub narzędzie do osiągnięcia innego celu. Istotny jest także kontekst, w którym autonomia jest realizowana.

Mój artykuł koncentruje się na procesie decyzyjnym towarzyszącym migracji oraz na pragnieniach i aspiracjach kobiet. Wychodzę poza paradygmat ekonomicznej racjonalności, który długo zajmował niemalże nienaruszalne miejsce $w$ teoriach migracji (Carling, Collins 2018). Paradygmat ów opiera się na założeniu, że migracja jest jedynie rezultatem skalkulowanego, racjonalnego wyboru, odbywającego się w pojedynczym wycinku czasu. Tymczasem migracja to nie pojedynczy akt, ale toczący się proces, w którym przeszłość, teraźniejszość i przyszłość są połączone. Życie migrantów wyłania się z tego procesu, a cechą migracji jest nieprzewidywalność, której doświadczają migranci, i o której co raz częściej przekonują się nie tylko obserwatorzy zjawiska, ale także politycy usiłujący zarządzać i kontrolować przepływy ludzkie (Collins 2018). Co więcej, migranta nie można zredukować do kalkulującej niezależnej jednostki, bo jest on poddawany wielu nakładającym się na siebie, czasem sprzecznym siłom i procesom, w kontekście których podejmuje działania. Na potrzeby poniższego artykułu, poświęconego doświadczeniom polskich migrantek w Norwegii, szczególne znaczenie mają negocjacje dotyczące migracji w świetle ról płciowych i obowiązków związanych z opieką nad członkami rodziny (Bielecka-Prus i in. 2018, Krzyżowski i in. 2017, Radziwinowiczówna 2018, Bastia 2013, Baldassar i in. 2007).

W artykule przyjmuję alternatywne do ekonomicznej racjonalności ramy koncepcyjne. Skupiam się na formowaniu migracji, na spotecznych i czasowych warunkach, które służą jako siła napędowa i podtrzymująca przemieszczenia (Carling, Collins 2018: 913). W tym alternatywnym podejściu na pierwszy plan wychodzą pojęcia aspiracji (aspiration) i pragnienia (desire) jako czynniki napędzające migracje (drivers of migration). Takie ujęcie uwzględnia zarówno rolę działań migrantek, jaki i strukturalne warunki w kraju ich pochodzenia i imigracji. Dotyczy to inicjowania, jak i podtrzymywania migracji. Rzeczywistość migracyjna jest dynamiczna i wyłania się ze wzajemnego oddziaływania indywidualnych podmiotów społecznych, które są obdarzone zdolnością do działania, wprowadzania innowacji i reinterpretowania rzeczywistości w celu spełnienia swoich pragnień z jednej strony (Bakewell 2010), oraz czynników mikro- i makrostrukturalnych takich, jak rynek pracy, polityka prowadzona przez rządy i kultura kraju, do którego migrant przybył - z drugiej (Morawska 2001). Można stwierdzić, że działania migrantów są strukturalnie uwarunkowane, ale niezdeterminowane, ponieważ jako aktorzy społeczni są oni obdarzeni indywidualną zdolnością do działania.

Chociaż teoretyczne analizy migracji zorientowane na aspiracje wciąż czekają na szersze rozwinięcie, aspiracje migracyjne (migration aspiration) pojawiają się w literaturze przedmiotu w podwójnej roli (Carling, Collins 2018). Po pierwsze, w kontekście 
stosunku, jaki ma działający podmiot wobec migracji. Można to wyrazić jako przekonanie, że wyjazd będzie lepszym rozwiązaniem niż pozostanie w kraju. Po drugie, aspiracje migracyjne pojawiają się jako nadrzędna kategoria obejmująca sformułowania, takie jak pragnienie (desire), chęci (wishes) i preferencje (preferences). Warto też przywołać definicję aspiracji, którą posługują się badacze edukacji, gdyż - jak sami zauważają - analiza osiągnięć zasługuje na uwagę nie tylko w kontekście wykształcenia i wykonywanego zawodu, ale szerzej jakości życia. Aspiracja to umiejętność identyfikowania i wyznaczanie sobie celów na przyszłość, będąc zainspirowanym do teraźniejszej pracy, aby je osiągnąć (Quaglia and Cobb 1996: 130). Oprócz samych osiągnięć ważne są jednak ograniczenia i możliwości działania (Sen 1993), co przekłada się na konkretne migracyjne zagadnienia badawcze: w jaki sposób i w jakich warunkach jednostka może działać, pomimo strukturalnych ograniczeń i jakie są efekty jej działań, to znaczy jaką indywidualną i społeczną zmianę przyniosły jej działania (Nare 2014).

Wykorzystanie kategorii pragnienia w analizie migracji oznacza zwrócenie uwagi, jak mobilność jest prowokowana przez zakres świadomych i podświadomych oddziaływań, którym podlegają jednostki (Collins 2018). Pojęcie pragnienia i układu (assemblage) jako narzędzi analitycznych w badaniu migracji zapożycza Francis L. Collins od Gilles'a Deleuze'a i Felixa Guattari (1983). Pragnienie nie jest zredukowane do prostej przyczyny migracji. Migracja jest wyrazem pragnienia, które wydobywa się z różnorodnych układów, składających się ze zróżnicowanych części ${ }^{6}$ połączonych w funkcjonalną całość. Te układy mają pewne cechy (Muller 2015). Są relacyjne - pozostawiają poszczególnym elementom pewną autonomię - i stwarzają możliwości działania. Tworzą terytoria i scalają je, a jednocześnie nieustannie przetwarzają je i rozsadzają. Ważną cechów układów jest to, że tworzą nowe terytorialne organizacje, nowe zachowania, nowych aktorów i nowe warunki. Są dynamiczne. Nie ma natomiast żadnych założeń, co do tego, jakie elementy mogą pozostawać ze sobą w związku.

W kontekście migracji pragnienie może wyrażać się w różnorakich formach takich, jak tożsamość globalna czy kosmopolityczna, poczucie zobowiązania wobec rodziny czy zaangażowanie w społeczność lokalną, chęć podróżowania i przeżycia przygody czy ucieczki przed społecznymi i instytucjonalnymi ograniczeniami itd.

Przejście od potencjalnego do realnego stanu migracji wyraża się w złożonej zależności pomiędzy strategicznym planowaniem i oportunizmem, co manifestuje się w mobilności, która ma służyć osiągnięciu lub uniknięciu przez jednostkę pewnych rodzajów przyszłości. (Collins 2018: 977)

Pojęcia zarówno aspiracji i pragnienia w odniesieniu do stosunku, jaki mają ludzie do migracji nie dają się oderwać od nastawienia społecznego. Oczekiwania i standardy

6 Elementy składowe układu to ludzie, zwierzęta, przedmioty oraz treści, a ich istotność w układzie jest nie tyle rezultatem ich natury, co sposobu organizacji układu. 


\section{SM̂PP}

grupy wpływają na aspiracje jej członków. W tym sensie oba pojęcia są ugruntowane społecznie. Przekonanie, że migracja niesie ze sobą pozytywny potencjał, jest także instytucjonalnie osadzone, co opisane jest już w literaturze pod innym pojęciem kultury migracji (culture of migration) (Romaniszyn 2003, Syed 2007, Connell 2008). Podobnie mechanizm dyfuzji (diffusion) wyjaśnia, jak osiągnięcia migrantów, obserwowane w społecznościach wysyłających przez osoby nieangażowane w wyjazdy, przyczyniają się do tego, że migracje jawią się jako realna szansa, co wpływa z kolei na rozwój aspiracji migracyjnych (Kandel and Massey 2002, Romaniszyn, 1997, 2003).

W trakcie migracyjnego projektu oczekiwania migrantów mogą się zmieniać. Coraz większa płynność struktur społecznych, opisana w koncepcji drugiej nowoczesności, późnej nowoczesności czy też płynnej nowoczesności, przejawia się w coraz większej podatności na zmiany, wiąże się z doświadczaniem większej bezradności (bo zmiany wykraczają poza wszelkie oczekiwania i wymykają się jego kontroli), prowizoryczności, ale też w obyczajowej i prawnej różnorodności (Beck, Lau 2005, Giddens 2010, Bauman 2006). Planowanie dążeń życiowych wymaga więcej wysiłku, bo wiąże się z elastycznością i adoptowaniem do zmieniających się okoliczności w sytuacji ryzyka i niepewności.

W rozważaniach nad autonomią migrantek warto też przywołać pojęcie lifestyle migration, ale traktując je, jak to proponują Michaela Benson i Karen O’Reilly (2016), jako narzędzie analityczne. Zgodnie z tym podejściem w badaniach pod uwagę należy brać to, jak czynniki ekonomiczne przecinają się ze stylem życia, tzn. jaką rolę w mobilności odgrywają wyobrażenia i aspiracje, co to sposobu życia. W takim ujęciu migracja to poszukiwanie, projekt, wolny wybór w dążeniu do pewnego sposobu życia. Projekt ten obejmuje różnorodne kierunki, oczekiwania i marzenia, przy czym wybór miejsca zamieszkania jest świadomym i intencjonalnym wyborem tego, jak żyć.

\section{Metodologia}

W celu przeanalizowania kwestii autonomii kobiet w kontekście migracyjnym odwołuję się go narracji migrantek. Wydaje się, że jest ona najbardziej użyteczna dla zbadania pragnień, aspiracji i nieprzewidywalnych wyników migracji. Opowieści migrantek łączą relacje dotyczące mobilności w wymiarze geograficznym i czasowym. Skupiają się na tym, jak Polki znalazły się w Norwegii, na ich wyobrażeniach o migracji, na osobach i instytucjach zaangażowanych w mobilność, ale także na ich własnym zaangażowaniu w kształtowanie migracyjnego projektu. Przede wszystkim jednak rozmówczynie dzielą się opowieścią o tym, jak kształtują swoją przyszłość poprzez teraźniejsze i przeszłe działania. Biograficzna perspektywa umożliwia zrozumienie aspiracji i ich zmiany, bo aspiracje są częścią biograficznego zasobu wiedzy jednostki (Berger i Luckmann 2010). Pozwala też na zrozumienie tego, jak kobiety negocjują i dokonują wyborów osadzonych w codziennych relacjach społecznych. 
W artykule przedstawiam analizę czterech wywiadów z kobietami, które do pracy za granicę wyjechały samodzielnie. Pierwszy wywiad przeprowadziłam w sierpniu 2017 roku w Oslo. Wybrałam go spośród ośmiu wywiadów z dziadkami (sześciu wywiadów indywidualnych, i po jednym grupowym i z parą, z w sumie z dziewięcioma kobietami i dwoma mężczyznami). Rozmawiałam o doświadczeniach związanych z byciem babcią/dziadkiem mieszkającą/cym w Norwegii, niezależnie od tego, w jakim kraju mieszkały wnuki. Podczas rozmowy poruszałam kwestie relacji rodzinnych i wyzwań związanych z migracją do Norwegii. Zastosowałam technikę wywiadu swobodnego ukierunkowanego (Przybyłowska 1978, Konecki 2000). Rozmowy prowadziłam uzbrojona w listę zagadnień, które chciałam poruszyć, ale pozostawiałam sobie elastyczność, w tym jak i kiedy zadać pytania.

Drugi wywiad przeprowadziłam w Oslo w sierpniu 2018 roku w ramach przygotowań do wystąpienia na konferencji Kobiece utopie w działaniu. 100 lat praw wyborczych kobiet (1918-2018) zorganizowanej przez Komitet Socjologii Polskiej Akademii Nauk i Instytut Socjologii Uniwersytetu Jagiellońskiego. Zależało mi na odpowiedzi na pytanie, czy w kontekście migracji rozmówczyni zyskała większą czy też mniejszą kontrolę nad własnym życiem. Zastosowałam technikę wywiadu swobodnego mało ukierunkowanego (Przybyłowska 1978, Konecki 2000). Rozmowę rozpoczęłam otwierającym pytaniem: Jak to się stało, że znalazłaś się w Norwegii i jak Ci się tu żyje? Pozwoliłam rozmówczyni mówić i otwierać przede mną jej własną perspektywę. Kolejne zadawane przez mnie pytania nawiązywały do jej narracji. Nie był to zatem wywiad narracyjny, w którym opowieść o życiu jest spontaniczną narracją, niezakłóconą interwencją badacza (Kaźmierska 1997).

Dwa pozostałe wywiady wybrałam spośród dziesięciu udostępnionych mi (z łącznie 30 przeprowadzonych) wywiadów indywidualnych lub z dwoma małżonkami. Rozmowy prowadzone były zimą i wiosną 2014 roku, w Oslo i okolicach. Użyto w nich kombinacji technik biograficznej i narracyjnej. Pochodzą z projektu Transfam.

Biograficzną część wywiadu otwierała prośba o opowiedzenie w pierwszej kolejności historii życia, następnie o przywołanie wydarzeń i doświadczeń, które były dla rozmówczyń ważne (Single-Question-Inducing-Narrative, Wengraf 2001). Snucie opowieści było łatwiejsze dzięki użyciu narzędzia wizualnego. Rozmówczynie nanosiły na linię życia ważne dla siebie wydarzenia. Druga część rozmowy opierała się na częściowo ustrukturyzowanym scenariuszu. Pytania obejmowały istotne obszary życia rodzinnego, które nie pojawiły się w pierwszej części biograficznej lub nie były jasne. Wywiad kończył się wykorzystaniem narzędzia wizualnego - prośbą o sporządzenie przez rozmówczynię koncentrycznych kręgów. Umożliwiało to dyskusję o sieciach społecznych istotnych w negocjowaniu multilokalnych i międzykulturowych wartości w transnarodowych układach krewniaczych (Ślusarczyk, Pustułka 2015).

7 Zebrane zostały w ramach zadania 2. Rodziny migranckie w Norwegii/struktury relacji władzy i negocjacji wartości oraz norm w rodzinach transnarodowych (lider: Magdalena Ślusarczyk). 


\section{SM̂PP}

Proces analizy wszystkich czterech wywiadów uwzględniał rekonstrukcję chronologicznego porządku doświadczenia migracyjnego. Poszczególnym fazom biografii przypisałam odpowiadające im pragnienia, aspiracje, proces podejmowania decyzji oraz sposób realizacji pragnień. Interesował mnie wymiar subiektywny doświadczeń rozmówczyń i ich sposób odnoszenia się do własnego życia. Materiał z wywiadów służył odpowiedzi na pytanie: jak wygląda proces budowania/ograniczania autonomii kobiet w kontekście migracyjnym? Odtworzenie poszczególnych biografii nie było dla mnie celem, a środkiem służącym odpowiedzi na to pytanie badawcze. Użyłam zatem perspektywy biograficznej, ale nie prowadziłam badań biograficznych. To bardzo istotne rozróżnienie, jeśli chce się uniknąć niefrasobliwego szafowania terminologią związaną z warsztatem metodologicznym (Kaźmierska 2013: 7).

\section{Analiza wywiadów z polskimi migrantkami w Norwegii}

\section{Rozmówczyni 1 (sierpień 2017)}

W chwili przeprowadzania wywiadu rozmówczyni miała 56 lat, od 30 lat była rozwiedziona i od ponad dwóch mieszkała w Norwegii, do której, przyjechała jak to się mówi w cudzysłowie za miłością. Nie planowała jednak na stałe zostać w Norwegii.

Urodziła się i mieszkała na tak zwanych Ziemiach Zachodnich. Bardzo wcześnie wyprowadziła się od męża i z maleńką córką wróciła do mieszkania rodziców, którzy jej pomagali. Razem z młodszym bratem mieszkała z nimi do ich śmierci (najpierw matki, potem ojca). W Polsce pracowała jako sprzedawczyni, ale prowadziła też sama sklep. Przed przyjazdem do Norwegii opiekowała się osobami starszymi w Niemczech. Dwa miesiące spędzała w Polsce, dwa miesiące pracowała za granicą. Temat decyzji związanej z pracą w Niemczech i samej pracy nie został rozwinięty. Pojawił się tylko w tle deklaracji mojej rozmówczyni, że nie wyobraża sobie na stałe życia poza Polską.

Jej opowieść dostarcza ciekawego materiału w kontekście zdolności do dokonywania wyborów dotyczących własnego życia i podejmowania działań w celu realizacji pragnień. Kobieta wykazuje się dużą refleksyjnością, co wiąże się z procesem uwalniania od uzależnienia. Kilka lat temu zaczęła stawiać pierwsze kroki ku nowemu, lepszemu życiu. Sądząc po tym, że odeszła od męża jako bardzo młoda osoba z niemowlęciem na ręku, można stwierdzić, że wykazała się wysokim poziomem autonomii. Potrafiła zerwać niedobrą dla niej i dziecka relację. Z opowieści, poza stwierdzeniem rodzice bardzo mi pomagali, nie dowiadujemy się więcej o tym, jak układały się jej relacje z rodzicami w dorosłym życiu. Jednak powrót dorosłej osoby do domu rodzinnego i wspólne mieszkanie z rodzicami musiało wymagać (re)definiowania ról i relacji w rodzinie. Z pozycji teraźniejszości dostępny jest nam komentarz dotyczący skomplikowanych stosunków rozmówczyni z jej własną córką, 
które kiedyś były według rozmówczyni bardzo złe. Z jednej strony kształtowane przez nieumiejętność powstrzymania się od ingerowania w życie dorosłej już córki, z drugiej - przez oczekiwanie, że córka będzie służyć matce radą i za nią decydować.

Kontroli nad własnym życiem nie można traktować jako sytuacji zero-jedynkowej. Nie można jej również traktować statycznie. Na różnych etapach życia rozmówczyni udaje się osiągnąć jej wyższy poziom, na kolejnych niższy, aby później zacząć odzyskiwać ją na nowo. Migracja wpisuje się i przeplata z tym procesem. Poziom autonomii w momencie podejmowania decyzji o migracji, zarówno do Niemiec i Norwegii, był wysoki. Wiązał się z tym, że rozmówczyni jako osoba rozwiedziona, której rodzice nie żyją, nie musiała podejmować negocjacji dotyczących ról płciowych i obowiązków opiekuńczych nad dorosłymi członkami rodziny. Co więcej dorosła córka nie liczyła na jej pomoc finansową i opiekę nad wnukami. Dała jej swojego rodzaju przyzwolenie:

Żeśmy rozmawiały, że ja mam myśleć o sobie. „Jesteś moją matką, dobrze, fajnie, cieszę się, ale ja mam swoją rodzinę." (...) Jestem w ogóle bardzo dumna i bardzo się cieszę z tego, że im się tak, jakoś układa, że mają tę głowę na karku. (...) Jestem bardzo dumna i bardzo zadowolona, dlatego że nie ciągnie ode mnie (...) pieniędzy.

W przypadku rozmówczyni wyjazd do Norwegii jest realizacją pragnienia innego lepszego życia, bliskości z drugim człowiekiem (wyjazd za miłością). Potrzeba innego życia jest tak silna, że podejmując decyzję o wyjeździe i o jego czasie rozmówczyni nie konsultuje się nawet z córką, wykazując się wysokim poziomem autonomii. Ten wyjazd, jak i poprzedni do Niemiec możliwy jest dzięki swobodzie przemieszczania i dostępności rynków pracy w obu krajach, którymi cieszą się obywatele UE. Znaczenie ma też zapotrzebowanie na usługi opiekuńcze i sprzątanie w wysokorozwiniętych gospodarkach oraz brak stabilności zatrudnienia w Polsce, związany z neoliberalnym charakterem reform gospodarczych. To wszystko razem tworzy obszar możliwości, z których rozmówczyni korzysta. W realizacji jej aspiracji migracyjnych istotne są też osoby i instytucje, które napotyka na swojej drodze, które są elementami układu migracyjnego. W opowieści brakuje opisu okresu pobytu w Niemczech, ale dowiadujemy się, że w Norwegii przy pomocy przyjaciółki założyła firmę jednoosobową.

Biorąc pod uwagę współczesną mobilność rozmówczyni, to jednym z czynników ją napędzających może być też szerszy kontekst historyczny i doświadczenia rodzinne. Jej życie naznaczone jest przez masowe przemieszczenia terytorialne, które nastąpiły w wyniku drugiej wojny światowej i zmiany granic państwowych oraz procesy industrializacji, odbywające się w realiach gospodarki centralnie planowanej. Ojciec rozmówczyni jeździł po delegacjach. Gdy rozmówczyni miała sześć lat po prostu wylądowali w mieście na zachodzie Polski. Potem już brat też się urodził i tak zostało. W dzieciństwie, w okresie dorastania i w życiu dorosłym brakowało mojej rozmówczy174 ni kontaktów z dalszą rodziną i krewnymi, którzy mieszkali na drugim końcu Polski. 


\section{SM̂PP}

Także transformacja gospodarcza, szczególnie jej neoliberalny kierunek i jego konsekwencje wraz ze zmianami demograficznymi (starzenie społeczeństw), zapotrzebowanie na pracę w sektorze opiekuńczym, bliskość granicy, rozwinięta sieć formalnych i nieformalnych instytucji ułatwiających znalezienie pracy w Niemczech oraz możliwość swobodnego przepływu ludzi wewnątrz UE - to wszystko czynniki kształtujące oczekiwania i aspiracje migracyjne nie tylko mojej rozmówczyni, ale także innych Polek. W takich okolicznościach jako podmioty społeczne obdarzone zdolnością do działania, wprowadzania innowacji i reinterpretowania rzeczywistości dążą one do spełnienia swoich pragnień i tworzą swoje indywidualne biografie, których częścią jest migracja.

Jak już wspomniałam w części wprowadzającej w kontekst teoretyczny, migracja to nie pojedynczy akt, ale toczący się proces, w którym przeszłość, teraźniejszość i przyszłość są połączone. Życie migrantów wyłania się z tego procesu, przy czym istotną jego cechą jest nieprzewidywalność. Tak też jest w przypadku rozmówczyni, która założyła swoją firmę. Chociaż w perspektywie kilku lat chce mieszkać i pracować w Norwegii, żeby zapracować na emeryturę, to:

Na pewno nie zostanę tu na stałe, na pewno wrócę do Polski. To znaczy nie lubię mówić tego słowa "na pewno", bo nie wiem, co będzie. Ale będę się starała.

Przed migrantami mogą pojawiać się wciąż nowe możliwości. Moja rozmówczyni wspomina: miałam taką rozterkę, bo w końcu zeszłego roku dostałam ponownie propozycję objęcia pracy. Migranci stają przed koniecznością dokonywania wyborów i zmiany migracyjnych ścieżek, co nie jest łatwe: Bardzo się biłam z myślami, bardzo ciężko mi było decyzję podjąć.

Ostatecznie rozmówczyni w chwili przeprowadzania wywiadu wciąż była w Norwegii, ale starała się jak najczęściej jeździć do Polski, chociaż chwilę, gdzieś tak naładować akumulatory dziećmi, wnukami, Polską. Taki stan rzeczy jest możliwy dzięki rozwojowi transportu, środków komunikacji i mediów społecznościowych. Pozwalają one na jednoczesne funkcjonowanie w obu krajach, co opisane jest w literaturze w kontekście współczesnych migracji analizowanych z perspektywy transnarodowej (np. Vertovec 2012, Beck, Beck-Gernsheim 2013).

\section{Rozmówczyni 2 (sierpień 2018)}

W chwili przeprowadzania wywiadu rozmówczyni (zamężna) miała 36 lat i siedmioletnie dziecko. Trzyosobowa rodzina mieszkała w Norwegii. Rozmówczyni pierwsza tu przyjechała do pracy i sprowadziła najpierw męża, a potem już razem z nim dziecko. W kontekście decyzji o wyjeździe wykazuje się bardzo wysokim poziomem autonomii. To ona jest inicjatorką migracji, która w początkowym zamierzeniu ma być krótkim samodzielnym wyjazdem, aby zebrać środki pozwalające na zmianę trybu pracy 
w Polsce. Jednakże rozpatrywanie jej historii jedynie w kontekście ekonomicznym migracji zarobkowej - byłoby nieusprawiedliwionym uproszczeniem.

Wykorzystanie pojęcia pragnienia, aspiracji i autonomii pozwala na głębsze zrozumienie procesu migracyjnego. Odwołanie się do układu migracyjnego pozwala natomiast zrozumieć, jak znalazła się w Norwegii i jak mogła przez pewien czas funkcjonować na nieformalnym rynku pracy, mieszkać i żyć w Norwegii bez znajomości języka angielskiego i norweskiego. Z kolei perspektywa lifestyle migration pozwala lepiej przedstawić, jak samotny wyjazd do pracy przerodził się w migrację rodzinną. Na funkcjonowanie rozmówczyni w Norwegii warto też spojrzeć z perspektywy kapitału migracyjnego (Łukasiuk 2007: 46-47), a więc kompetencji potrzebnych człowiekowi do zainstalowania się w nowym miejscu. Jest to rodzaj kapitału kulturowego w rozumieniu Bourdieu (Bourdieu, Wacquant 2001), a składają się na niego pewne umiejętności nabyte podczas migracji, odnoszące się do wyuczonej adaptywności (Łukasiuk 2007: 47):

Migranci uczą się, jak poznaje się nowe miejsce, jak poznaje się nowe towarzystwo, jak można radzić sobie z samotnością, jak gospodarować zasobami finansowymi, jak szukać pracy, mieszkania, rozrywki.

Co istotne poziom tego kapitału podwyższa się wraz z kolejnymi doświadczeniami migracji, a więc swego rodzaju treningiem migracyjnym. Migrant staje się sprawniejszy w uruchamianiu potrzebnych umiejętności i pozyskiwaniu zasobów, a dzięki temu łatwiej instaluje się w nowych miejscach zamieszkania. Rozmówczyni pochodzi z małej miejscowości. Po ukończeniu zaocznych studiów podjęła w niej pracę w swoim zawodzie, ale w wyniku upadku dwóch ważnych pracodawców na lokalnym rynku podejmuje decyzję o przeprowadzeniu się do innego regionu, z którego pochodzi poznany na studiach mąż. Migracja wewnętrzna jest pierwszym etapem na jej migracyjnej ścieżce. Doświadczenie z nią związane sprawiło, że w Norwegii kobieta nie koncentrowała się na poczuciu wyobcowania, bo za drugim razem jest łatwiej przejść coś takiego. Rozmówczyni skupiała się na tym, co miało ją zbliżyć do spełnienia pragnienia - życia, w którym udaje się utrzymać równowagę pomiędzy pracą i rodziną. Opis jej codzienności w Polsce oddaje warunki, w jakich funkcjonuje wiele osób na tzw. „dorobku” w realiach wolnorynkowej gospodarki. Praca po dwanaście, trzynaście godzin dziennie, także w soboty, ponieważ trzeba spłacać kredyt zaciągnięty na kupno domu. W jej przypadku istotną rolę odegrał stres związany z zajmowanym przez nią stanowiskiem i nakłanianiem przez przełożonych do łamania prawa pracy oraz zasad bezpieczeństwa i higieny pracy. Ważną część narracji, opisującej życie w obu krajach, stanowi napięcie spowodowane niemożnością realizowania się jako matka. W Polsce dziecko się przyzwyczaiło, że mama jest non-stop w pracy, a nie ma jej w domu, bo takie były wymagania. W Norwegii szefostwu po prostu dziecko przeszkadzało i to był taki pierwszy sygnał dla rozmówczyni, żeby myśleć o zmianie pracy. 


\section{SM̂PP}

Można powiedzieć, że właśnie to napięcie, między oczekiwaniami rozmówczyni a okolicznościami, jest elementem, który mobilizuje ją do podejmowania działań. Jej opowieść pokazuje, jaką rolę w mobilności odgrywają wyobrażenia i aspiracje, co do sposobu życia. Wybór miejsca zamieszkania jest świadomym i intencjonalnym wyborem tego, jak żyć:

Widziałam duże perspektywy i duże możliwości zwłaszcza rozmawiając z innymi ludźmi, którzy całymi rodzinami przyjechali.

Jej migracja to poszukiwanie, projekt, wolny wybór w dążeniu do pewnego sposobu życia. Ten wątek odnaleźć można także w opowieści pierwszej rozmówczyni. Obie dochodzą do wniosku, że poza Polską, przynajmniej na razie, mogą realizować swój życiowy projekt.

Zamiast się dopasowywać do tego, co rozmówczyni nie odpowiada, wykazała się ona aktywną postawą, przekształcając rzeczywistość: uważam, że dziecko mam jedno, a pracę można zawsze zmienić. Nie działała pod wpływem impulsu, ale starannie planowała (żebym mogła się zabezpieczyć na dwa razy, w razie czego, do czego wrócić), negocjowała z mężem. W kwestii wzięcia kredytu na dom, wyjazdu za granicę czy zmiany pracy, to ona była inicjatorką. Mężczyzna wspierał ją w podejmowanych decyzjach, ale też, co istotne, a bliżej będzie opisane nieco później, stwarzał możliwości, w których rozmówczyni może działać. Motyw „zabezpieczania się" obecny jest w całej narracji i dotyczy różnych aspektów. Planowanie dążeń życiowych wymaga wysiłku, bo wiąże się z elastycznością i adoptowaniem do zmieniających się okoliczności w sytuacji ryzyka i niepewności:

Muszę powiedzieć, że człowiek też bardzo się zastanawiał, czy ściągać dziecko czy nie, czy wracać. Co zrobić, jak to ułożyć? No, ale jak na razie jesteśmy tutaj. I nie jest źle, można powiedzieć. A co będzie dalej, to się okaże.

Działania migrantów są strukturalnie uwarunkowane, ale niezdeterminowane, ponieważ są oni obdarzeni indywidualną zdolnością do działania i wykorzystywania bądź nie pojawiających się możliwości. Przyjmują różne postawy wobec ograniczeń starają się je pokonać w niekoniecznie formalny i zgodny z obowiązującymi przepisami sposób lub pozwalają, aby ograniczenia zablokowały przynajmniej na pewien czas ich migracyjne aspiracje. W realizacji zamiaru wyjazdu za granicę, rozmówczyni skorzystała z pomocy innej migrantki (swojej szwagierki), ale też z możliwości, jakie daje obywatelstwo kraju UE, swobodnego przepływu osób w Europejskim Obszarze Gospodarczym. Staje się częścią układu migracyjnego, przy czym nie tylko z niego korzysta, ale go buduje:

Zaczęłam namawiać (męża - przyp. Autorki), że może tu będzie lepiej, może spróbujmy, może przyjedziesz, znajdziesz pracę, może się uda, wtedy większe mieszkania gdzieś wynająć i dziecko ściągnąć. 
Podejmując decyzję o szukaniu pracy za granicą wykazała się wysokim poziomem autonomii. Pobytu w Norwegii wiązał się z ogromną determinacją, której towarzyszyło czasowe ograniczenie autonomii (ze względu na tryb i status pracy) i ogromne koszty emocjonalne:

Tęskniłam strasznie, człowiek będąc w obcym miejscu (łzy i załamujący się głos od tej pory - przyp. Autorki) no to po prostu można powiedzieć - cierpi. (...) miałam tę świadomość, że (dziecko - przyp. Autorki.) jest z moją mamą i jest ok. (...) Jak miałam takie ciężkie sytuacje, to sobie zawsze mówiłam, że to robię dla (imię dziecka, prawie płacz przyp. Autorki), nie dla siebie, tylko dla (imię dziecka - przyp. Autorki), żeby mu kiedyś było w życiu łatwiej.

Tak długo, jak moja rozmówczyni była sama, godziła się na nieformalny status zatrudnienia. Dopasowywała się do tego, jak postrzegała swoje możliwości i ograniczenia. Nie znała języków obcych, więc intensywnie (ale poza formalną edukacją) starała się nauczyć norweskiego, towarzyszyło jej przy tym przekonanie, że nie ma zdolności do nauki języków obcych. Dla Polki, która ją nieformalnie zatrudniała w firmie sprzątającej, była można powiedzieć 24 godziny na telefon. Jej oczekiwania związane z pracą w Norwegii zmieniały się wraz ze pojawiającymi się okolicznościami i możliwościami. Mężowi, dzięki znajomości angielskiego, łatwiej było znaleźć rejestrowaną pracę, co pozwoliło w końcu sformalizować sytuację pobytową rozmówczyni. Pojawiła się nowa możliwość - skorzystanie z procedury łączenia rodziny. Pozwoliła ona pokonać ograniczenia, z którymi borykała się rozmówczyni, która wprawdzie do Norwegii przyjechała przed mężem, ale funkcjonowała, bez formalnych podstaw do podjęcia działań służących uzyskaniu zgody na pobyt.

Momentem zwrotnym stał się przyjazd dziecka, które wcześniej było u dziadków, którzy także są elementem układu, bez którego do mobilności rozmówczyni by nie doszło. Po połączeniu rodziny rozmówczyni nie od razu zmieniła pracodawcę, ale sformalizowała stosunek pracy i zaczęła egzekwować warunki umowy, żeby móc zajmować się dzieckiem. Zanim je sprowadziła przez pewien czas dalej pracowała w niesformalizowany sposób i mieszkała z mężem w wynajętym pokoju, w mieszkaniu dzielonym przez kilkoro imigrantów (z Polski i innych państw). Takie wspólne mieszkanie jest rozwiązaniem możliwym dzięki układowi migracyjnemu - istnieniu firm i indywidualnych właścicieli nieruchomości specjalizujących się w oferowaniu mieszkań i domów, w których odnajmowane są pokoje, a reszta powierzchni wspólnie użytkowana przez mieszkańców - oraz rozwiniętej sieci nieformalnych kontaktów i mediom społecznościowym. Ten typ zakwaterowania można też znaleźć u innych Polaków, którzy w ten sposób obniżają koszty życia w Norwegii.

Mając z mężem stałą pracę mogli wynająć mieszkanie, w którym może dziecko po prostu mieszkać, czyli dziecko musi mieć oddzielny pokój. Mężowi rozmówczyni łatwiej było zmienić zatrudnienie na takie, w którym zarobki są wyższe. 


\section{SM̂PP}

czekała aż mężczyzna umocni pozycję na rynku pracy. Zwolniła się z pracy i otworzyła własną działalność. Oto jak opisywała swoje pragnienia na moment przeprowadzania rozmowy:

Nauczyć się języka, no bo to dla mnie można powiedzieć podstawa w obcym kraju, żeby komunikować się bez problemu w tym języku. No i zobaczymy, co będzie. Taki miałam faktycznie plan, to jest wcześniejsze spłacenie kredytu w Polsce. Żeby po prostu dom był nasz, a nie że tam jeszcze mamy jakiś tam kredyt w banku i tak dalej. No i wtedy może pomyśleć, żeby kupić tu mieszkanie, żeby no... Nie jestem osobą, która uwielbiałaby całe życie żyć na czynszach.

\section{Rozmówczyni 3. (wiosna 2014)}

W chwili wywiadu rozmówczyni miała 41 lat i wraz z mężem i dwójką dzieci urodzonych w Norwegii mieszkała w tym kraju. Wszyscy mieli obywatelstwo norweskie. Aby je przyjąć, zrezygnowali z polskiego (wymóg norweskich regulacji). Jej narracja jest o tyle ciekawa, że kobieta została zrekrutowana do pracy w Norwegii jeszcze przed wejściem Polski do Unii Europejskiej.

Podobnie do opowieści poprzedniej rozmówczyni, także w tym przypadku to kobieta jest inicjatorką migracji męża. Wykorzystała możliwość, jaką daje procedura łączenia rodziny. Wszystko odbywa się zgodnie z założeniami tej procedury - osoba mieszkająca i pracująca legalnie w Norwegii podejmuje działania, aby połączyć się z członkiem rodziny.

W Polsce rozmówczyni ukończyła studia na wydziale pielęgniarskim na Akademii Medycznej. Pracowała przez dwa lata, ale jak to określiła nie była spełniona $w$ tym zawodzie. Oczekiwała, że w pracy będzie wykorzystywać to, czego uczyła się na studiach i denerwowała się, po co mi te studia, jak ja muszę myć, zmieniać pościel. Skoro praca nie spełniała jej młodzieńczych aspiracji, podjęła studia podyplomowe (zarządzanie w służbie zdrowia). Gdy je ukończyła, także okazało się, że nie ma szans na wyższe stanowisko. W takich okolicznościach - zablokowanego awansu zawodowego, pomimo celowo podejmowanych działań, aby go uzyskać - pojawiła się przed nią, jak to określiła sama i jak to określili jej siostra i szwagier - szansa. Dostała propozycję pracy w zawodzie. Z późniejszej opowieści dowiadujemy się, że zakres pracy pielęgniarki w Norwegii jest szerszy w porównaniu do tego, jakiego doświadczyła w Polsce i co za tym idzie bliższy oczekiwaniom/pragnieniom wyniesionym przez rozmówczynię z czasów studiów. Dzięki kolejnym kursom i dokształcaniu kobieta awansuje. Odpowiada jej to, że pacjenci traktowani są z taką samą starannością bez względu na ich status społeczny.

Nie odnalazłam w narracji rozmówczyni śladów gorszego traktowania, wynikającego z przekonań norweskich współpracowników i pracodawcy o niższym poziomie przygotowania zawodowego polskich pielęgniarek. Jednakże na dyskryminację 
polskich pielęgniarek, wynikającą z przekonania, że Polska to nie do końca Europa, a brak biegłości w posługiwaniu się językiem norweskim jest równoznaczny z brakiem kwalifikacji zawodowych, wskazuje Françoise Micheline van Riemsdijk (2008, 207). Polki kierowane były do placówek (np. do domów opieki) oferujących mniejsze możliwości awansu. Nie były także w pełni zintegrowane w środowisku pracy, ze względu na postrzeganie ich przez współpracowników jako nie w pełni norweskie (tamże, 208). Być może moja rozmówczyni należy do tych polskich pielęgniarek, które dzięki swojej determinacji poprawiły warunki pracy (tamże, 209) albo celowo unika poruszania tej kwestii.

W przypadku tej rozmówczyni warto przywołać raz jeszcze pojęcie układu i wchodzących w jego skład różnych elementów. Firma rekrutująca pielęgniarki otworzyła przed nią nowe możliwości. Aspiracja migracyjna pojawiła się i mogła zostać spełniona dzięki pośrednikowi. Rozmówczyni go nie szukała, to on znalazł ją. W porównaniu z dwoma pierwszymi rozmówczyniami była w uprzywilejowanej sytuacji. Jeszcze przed wyjazdem w ramach oferty pracy uczestniczyła w kursie języka norweskiego, nie musiała szukać pracy, bo została do niej zrekrutowana w Polsce i od razu mogła spełniać pragnienia związane z pracą w wyuczonym zawodzie. Jednak sama decyzja o wyjeździe nie była łatwa i wpisywała się w kontekst relacji rodzinnych:

Mama chciała mnie zatrzymać. Natomiast siostra i siostry mąż, to oczywiście, "jak najbardziej - jedź!". Mnie blokowało to, że miałam dostać 100 zł podwyżki w tym szpitalu, w którym pracowałam.

Ostatecznie rozmówczyni, już jako osoba zamężna, wyjechała na rok. Jednak po roku stwierdziła z mężem, że zostanie jeszcze rok, ponieważ kredyt w Polsce na mieszkanie był itd. Narracja wskazuje, że chociaż wykazywała wysoki poziom autonomii w podejmowaniu decyzji o samodzielnym wyjeździe i pobycie za granicą, to uwzględniała opinie, często sprzeczne, swojej rodziny. To doskonale obrazuje, że wybory dokonywane przez kobiety osadzone są w codziennych relacjach. Ostatecznie wraz z mężem postanowiła, że po kolejnym roku ten spróbuje do niej dojechać. Ich zawodowa sytuacja była odmienna. Jego wykształcenie i kwalifikacje wymagały podjęcia specjalnych działań, aby je uznano w Norwegii. W początkowym okresie po połączeniu rodziny, kobieta przejmuje na swoje barki ogrom obowiązków, które w Polsce mogła dzielić z mężem:

Cały ten ciężar, ten motorek, spoczął jakby na mnie. (...) Tutaj tak mi się zdawało, że ten cały proces tych wszystkich kart, banków, prawa jazdy, to wszystko na mnie. Ale to raz, że wiedziałam, gdzie. Dwa, że byłam lepsza językowo i to było takie trochę obciążające.

Kiedy udało się uzyskać stabilizację (stałą pracę dla obojga i kupno mieszkania), przyszedł czas na powiększenie rodziny. Tutaj także widać wysoki poziom kontroli nad własnym życiem. Aby utrzymać ten stan i dalej realizować swoje pragnienia, 


\section{SM̂PP}

rozmówczyni wykorzystuje kolejny element układu migracyjnego - swoją matkę. Ograniczając, bądź ujmując to inaczej, na pewien czas zawieszając autonomię starszej kobiety, sprowadziła ją na kilka lat do Norwegii, gdzie stworzyła trzypokoleniową rodzinę.

Matka rozmówczyni wróciła do Polski, jak tylko było to możliwe (wykorzystuje szansę), tzn. kiedy młodsze z dzieci idzie do przedszkola w wieku trzech lat, a nie jak to jest przyjęte w Norwegii, gdy skończy rok. Kobiety negocjują dalszy udział babci w opiece nad wnukami:

Wrócić to by tutaj nie chciała, ale tak na trzy, cztery, pięć tygodni, żeby mi pomóc w lecie, bo przedszkole zamknięte, świetlica zamknięta, a urlopu nie ma tyle, to jakoś sobie układamy ten grafik.

Staje się w ten sposób „latającą babcią" (Bjornholt, Stefansen 2018, Nesteruk, Marks 2009). Takie rozwiązanie łatwiej zrozumieć, gdy weźmie się pod uwagę oczekiwania związane z solidarnością międzypokoleniową wyrażane przez Polaków powyżej 50 roku życia. Blisko 75\% z nich uważa, że pomaganie dorosłym dzieciom w opiece nad ich małym potomstwem jest obowiązkiem dziadków (za Krzyżowski 2011,61-62). Ten kontekst społeczny był także istotny w przypadku poprzedniej rozmówczyni, która zostawiła małe dziecko w Polsce pod opieką swojej matki. Wpisuje się też w opowieść pierwszej rozmówczyni, która jest babcią.

Gdy mówimy o autonomii, oprócz refleksji nad własnym położeniem, oceny różnych opcji, krytycznego ich przeanalizowania, kolejnym istotnym elementem jest wynegocjowanie strategii i podjęcia działań. Opis typowego dnia z życia rodziny dostarcza pola do analizy $w$ tym zakresie. W przypadku rozmówczyni opis dotyczący aktywności związanych z funkcjonowaniem rodziny z małymi dziećmi, która nie może już liczyć na regularną pomoc babci, przypomina opis dobrze działającej maszyny.

Zredukowałam sobie etat ze 100 proc. do 70 proc., więc pracuję tak 3 do 4 dni w tygodniu (...). To opowiem taki dzień, jak pracuję. Ja odprowadzam dzieci, potem zorganizuję wszystko $w$ domu, obiad ${ }^{8}$ itd. to, co należy do obowiązków i jadę do pracy na 15., a mąż odbiera dzieci tak w okolicach 16. ze szkoły i przedszkola. I oni wracają do domu. Mają obiad. Kolacja i spać. I ja wracam około 11. (...) Rano znowu ja wstaję i mąż też, bo jedzie do pracy. Szykuję, odprowadzam, szkoła, przedszkole, do domu, znowu do pracy.

Przejęcie na swoje barki gotowania i zwykłego sprzątania (jakieś większe akcje sprzątające, jak mycie okien, to musimy razem) rozmówczyni tłumaczyła tym, że ceni sobie ten czas z rodziną. Odkurzać woli w piątek jak wszyscy są w szkołach i przedszkolach, a tę sobotę spędzić razem (wspólne wyjścia na narty czy inny sport, posiedzieć razem w domu). Z powyższego opisu wywnioskować można, że przejmowanie

${ }^{8}$ Warto w tym kontekście zauważyć, że w szkołach w Norwegii dzieciom nie oferuje się obiadów. W trakcie pobytu w szkole jedzą to, co przygotowali im opiekunowie w domu. 
większej części obowiązków związanych z funkcjonowaniem rodziny jest kwestią wyboru rozmówczyni. Priorytetem jest czas spędzony wspólnie z dziećmi i mężem na przyjemnościach. Pod tym kątem zorganizowane są praca zawodowa i obowiązki domowe, a nawet wizyty rozmówczyni u fryzjera. Wykazuje się więc ona wysokim poziomem autonomii. Trudno jej również odmówić sprawczości, gdy pod uwagę weźmie się pionierski charakter migracji i to, że w pierwszych latach po przyjeździe męża ze względu na lepszą znajomość języka i Norwegii to ona była motorkiem. Przyjmując jednak inną perspektywę, można powiedzieć, że kontynuuje model macierzyństwa nawiązujący do wzoru Matki-Polki, który ewoluował po drugiej wojnie światowej, co trafnie opisała Anna Titkow (2012: 30):

Trudne warunki życia doprowadziły do powstania specjalnej odmiany „matriarchatu”, charakterystycznej dla komunistycznych i postkomunistycznych krajów Europy Wschodniej. Matriarchatu, w którym obładowana siatkami, często odczuwająca brak snu, strasznie zmęczona kobieta ma równocześnie uzasadnione poczucie bycia niezastąpionym menedżerem życia rodzinnego, wywiązującym się z niezliczonych obowiązków i zadań.

Podobnymi zdolnościami menedżerskim wykazuje się także opisana powyżej druga rozmówczyni. W obu narracjach odnajdujemy refleksję nad własnym położeniem, ocenę różnych opcji działania. Aspiracje obu rozmówczyń wpisane są w kontekst rodzinny. Obie zarządzają rodzinnymi zasobami, aby realizować swoje pragnienia. To wymaga negocjowania strategii i podjęcia działań przez same rozmówczynie i ich najbliższych. Istotna część możliwości otwiera się dzięki starszemu pokoleniu (gdy ich matki czasowo przejmują mniejszą lub większą część funkcji opiekuńczych) i mężom (dzielenie ryzyka na dwoje). W obu przypadkach, przejęcie pewnej kontroli nad własnym życiem wymaga współdziałania, dobrze zarządzanych elementów - to jest projekt rodzinny i wielopokoleniowy.

\section{Rozmówczyni 4 (wiosna 2014)}

W momencie przeprowadzania wywiadu kobieta miała 36 lat. Mieszkała z mężem Norwegiem i trójką dzieci w Norwegii. Podobnie jak w przypadku pierwszej rozmówczyni Norwegia nie była pierwszym krajem, do którego wyjechała. Po ukończeniu zaocznych studiów (licencjat) rozmówczyni znalazła stałą pracę i dalej mieszkała z rodzicami i rodzeństwem. Jej pragnienia wpisane są w trudną sytuację rodzinną jej ojciec był alkoholikiem. Jak to określiła: szukała ucieczki od swojego życia. Marzyła o wyjeździe do Stanów Zjednoczonych, ale wydawał się on poza zasięgiem młodej dziewczyny. Nie podejmowała żadnych kroków. Aby aspiracja migracyjna przeszła w fazę działania, potrzebny był pewien element - agencja au-pair. Rozmówczyni nie szukała możliwości wyjazdu. Informacja dotarła do niej za pośrednictwem młodszej siostry, która przyniosła ze szkoły ulotkę. I sobie poczytałam i sobie myślę: wcale takie trudne to nie jest. W tym momencie ocenie sytuacji towarzyszyły 


\section{SM̂PP}

działania podejmowane w celu realizacji pragnienia. Potrzebne było prawo jazdy, rozmówczyni zrobiła je. Oczekiwanie na odpowiedź od rekrutera przedłużało się. Jak się później dowiedziała rozmówczyni, wstrzymanie wydawania wiz związane było z tragicznym wypadkiem, w którym uczestniczyła jedna z au-pair. To niezależne od rozmówczyni wydarzenie zahamowało, ale nie przekreśliło realizacji aspiracji migracyjnej.

Po powrocie ze Stanów Zjednoczonych, w których spędziła ponad rok, rozmówczyni stwierdziła, że jest za młoda na biurową pracę od ósmej do szesnastej. Następuje ocena sytuacji - ok. mogę wyjechać jako au-pair do Holandii, bo w tym kraju nie wymagano poza angielskim znajomości innego języka obcego. W Holandii poznała swojego późniejszego męża - pracującego tam Norwega. Wszystko to odbywa się przed wstąpieniem Polski do UE, więc kiedy skończyła pracę, po dodatkowym miesiącu musiała wrócić do Polski. Kolejny raz pojawiła się przeszkoda spowalniająca realizację jej aspiracji migracyjnych, ale także tych dotyczących życia osobistego. Po dziewięciu miesiącach oczekiwania na wizę przyjechała do Holandii, zamieszkała z przyszłym mężem i w niespełna miesiąc za pośrednictwem koleżanki znalazła pracę w międzynarodowej fundacji. Wyszła za mąż, urodziła dwójkę dzieci. To właśnie w związku z nimi podjęła wspólnie z mężem decyzję o kolejnym przemieszczeniu tym razem całej rodziny do Norwegii, bo tam były fajne warunki do wychowywania dzieci, chcieli przedłużyć dzieciom dzieciństwo (w Holandii dzieci rozpoczynają naukę w szkole w wieku 4 lat, a Norwegii - 6). Rodzice pragnęli, aby dzieci dorastały w kulturze jednego z nich. Uznali, że kobiecie łatwiej będzie nauczyć się norweskiego i znaleźć pracę w Norwegii niż mężczyźnie opanować polski i pracować w Polsce. Taka ocena sytuacji zaważyła o kierunku dalszej migracji. Proces podejmowania decyzji o wyjeździe do Norwegii i sam wyjazd w przypadku rozmówczyni rozciągał się w czasie, co pozwalało na spokojne przygotowania (rozpoczęcie nauki języka norweskiego, bo z mężem porozumiewała się po angielsku, a z dziećmi po polsku). W Norwegii poszła do szkoły, żeby nauczyć się norweskiego. Opanowanie języka zajęło jej około roku. W tym czasie urodziła trzecie dziecko (była w ciąży przyjeżdżając do Norwegii). Poszła na kurs zorganizowany przez NAV (Norweska Agencja do Spraw Pracy i Opieki) z zakresu pracy biurowej i sekretarskiej, bo taki był charakter pracy, którą wykonywała w Polsce i później w Holandii. Chciała poznać specyficzne słownictwo związane z tą pracą.

Opis funkcjonowania kobiety w Norwegii odbiega od narracji pozostałych rozmówczyń. Dla niej początki to czas rozwoju, a nie pokonywania trudności w drodze ku zrealizowaniu pragnienia - połączenia rodziny w nowym miejscu. Jako żona norweskiego obywatela jest uprzywilejowana w stosunku do innych Polek:

Nie dość, że kurs jest za darmo, to płatne jest tak, jakby dzienna stawka. Plus opłacane jest przedszkole i dojazd na ten kurs, więc dla mnie, która nigdy w życiu nie pracowała w Norwegii, a tu pieniądze za to, że się uczę. 
W związku z tym, że w Holandii przywykła do międzynarodowego środowiska (nawet koleżanki Polki miały mężów pochodzących z różnych krajów, podobnie znajomi męża byli zróżnicowani pod kątem pochodzenia) zależało jej na znalezieniu pracy w takim otoczeniu. Jednak po dokonaniu oceny sytuacji (trójka dzieci, mieszkanie pod Oslo, mąż pracujący w Oslo), przeformułowała swoje oczekiwania. Aby móc zajmować się dziećmi, podjęła praktykę w okolicy domu w norweskim środowisku. W jej narracji nie odnajdziemy śladów zmagania się ze sobą, poczucia niespełnienia, co związane może być z charakterem rozmówczyni, ale także z oczekiwaniami dotyczącymi roli kobiety w rodzinie czy szerzej przekonań dotyczących płci (Taka opiekuńczość jest chyba we krwi). Mężczyzna koncentruje się na jednym zadaniu i jakoś nie myśli o chorym dziecku, a matka nie potrafi przestać myśleć. Można więc powiedzieć, że jest to swojego rodzaju samoograniczenie w zakresie realizacji jednych pragnień (spełnienie zawodowe), gdy inne wydają się ważniejsze (spełnienie w rodzinie). Oto jak opisała to rozmówczyni:

Wydaje mi się, że u nas jakoś tak naturalnie się dopasowaliśmy. To było takie, że może mój mąż szukał takiej bardziej kobiety domowej, która tam gotuje, dba i na takiej zasadzie. A to jakoś z domu to wyjęłam. Moja mama gotowała, zajmowała się praktycznie wszystkim w domu i ja tak przejęłam pałeczkę.

Analizując historię, którą podzieliła się rozmówczyni, stwierdzić należy, że kobieta wykazuje się zdolnością do refleksji nad własnym położeniem i oceny różnych opcji i podjęcia działań zmierzających do realizacji pragnienia: innego życia niż to, które miała w domu z ojcem alkoholikiem. Można więc powiedzieć, że poziom autonomii jest w jej przypadku wysoki. Reaguje na pojawiające się możliwości - dokonuje wyborów i podejmuje działania, które służą realizacji jej pragnień. Oczywiście jej pragnienia ukształtowane są przez wyobrażenia dotyczącego roli kobiety, której "naturalnym” elementem jest opiekuńczość. Osiedlenie w Norwegii nastąpiło w wyniku ciągu wielu zdarzeń, nakłada się na teraźniejszość (wysoka jakość życia, równowaga między życiem rodzinnym i pracą) i przyszłość (chciałaby, aby dzieci uniknęły chamstwa i cwaniactwa). Norwegię, podobnie jak poprzednie dwie rozmówczynie postrzega jako kraj większych możliwości wyboru. Na uwagę zasługują odczucia dotyczące pracy. Przewija się w nich kwestia szacunku dla człowieka jako pracownika, klienta/pacjenta bez względu na jego pozycję społeczną czy miejsce w strukturze. To wszystko przekłada się na jakość życia i zadowolenie z niego:

Tu jest na zasadzie, żeby pomóc drugiemu człowiekowi, a w Polsce jest czasami, żeby dokopać drugiemu człowiekowi. (...) W Polsce siedzi sfrustrowany kierowca autobusu, bo nic innego nie może robić. I o! wkurzają ludzie, bo jadą autobusem. A tutaj jednak większość ludzi ma pracę z wyboru i jest łatwiej zmienić pracę, zupełnie się przekierunkować.

Jak mnie pan zwyzywał (urzędnik w Polsce podczas jednej z wakacyjnych wizyt przyp. Autorki), to na koniec się poryczałam z takiej bezsilności. (...) Właśnie, że tutaj (w Norwegii - przyp. Autorki) ludzie wszyscy inaczej do siebie się zwracają. 


\section{SM̂PP}

\section{Konkluzje}

Artykuł odzwierciedla kierunek mojej refleksji towarzyszącej obserwacji migracji Polaków do Norwegii. Uzasadnieniem jego napisania są doświadczenia z nieformalnych sytuacji podczas kilkukrotnych wizyt w Norwegii oraz materiał badawczy zebrany w ramach projektu Transfam i własnych badań. Z każdym kolejnym pobytem, przekonywałam się, że analizowanie obecności Polaków w Norwegii, jedynie z perspektywy ekonomicznej motywacji nie oddaje jej bardziej złożonego charakteru.

Zależało mi na wskazaniu, że do analizy migracji Polek do Norwegii użytecznymi, to znaczy pozwalającymi lepiej zrozumieć specyfikę zjawiska, są pojęcia pragnienia, aspiracji i autonomii. W artykule przedstawiam sposób, w jaki można przeprowadzić analizę dysponując jakościowym materiałem, który interpretuje się z perspektywy biograficznej. Innymi słowy, pisząc artykuł nie zamierzałam wyczerpać problematyki autonomii polskich migrantek w Norwegii, a przedstawić inne spojrzenie na kwestię ich funkcjonowania, uzupełnić wnioski z badań. Wydaje mi się, że opracowania odwołujące się do zmian postaw czy ról płciowych w kontekście migracji w większym stopniu uwzględniać powinny równolegle toczące się procesy modernizacyjne i zmiany zachodzące w społeczeństwach wysyłających. A także to, że pragnienia, aspiracje i poziom autonomii zmieniają się na przestrzeni czasu wraz ze zmieniającymi się okolicznościami napotykanymi przez kobiety, i podejmowanymi (lub zaniechanymi) przez nie działaniami. Łączenie procesu migracyjnego z uwolnieniem się od sztywnego kulturowego gorsetu (Herzberg 2015: 182) to tylko jedna z możliwych opcji. Przeanalizowane pragnienia i aspiracje moich rozmówczyń są osadzone w kontekście rodzinnym. Narracja najstarszej rozmówczyni wyłamuje się nieco z tego schematu niezależna postawa córki, która założyła własną rodzinę, pozwala matce i babci na realizację jej indywidualnego pragnienia innego życia, poza Polską. Zdaję sobie sprawę, że waga kontekstu rodzinnego może być związana z doborem rozmówczyń wszystkie założyły rodziny. Ponadto trzy spośród czterech wywiadów przeprowadzone zostały w ramach badań odwołujących się z założenia do kontekstu rodzinnego. Jednak tego, że pragnienia i aspiracje w narracji migrantek, wiążą się raczej z dobrobytem rodziny niż ich indywidualnym interesem, nie można rozpatrywać w oderwaniu od wyników badań nad systemem wartości wyznawanych przez Polaków. Rodzina zajmuje w nim wysokie miejsce, a przytłaczająca część Polaków uważa, że jest ona niezbędna do osiągnięcia szczęścia9 ${ }^{9}$. Co więcej postrzeganie migracji przez

9 Szczęście rodzinne zajmuje niezmiennie pierwsze miejsce wśród najważniejszych wartości, jakimi Polacy kierują się w swoim codziennym życiu (CBOS 2008, 2013, 2019). Na początku 2019 roku w odpowiedzi na polecenie Ludzie kierują się różnymi wartościami w życiu. Z podanej listy proszę wskazać nie więcej niż pięć wartości, które uważa Pan(i) za najważniejsze w swoim codziennym życiu aż 80\% wskazało właśnie szczęście rodzinne. Przy czym kobiety częściej niż mężczyźni, odpowiednio 86 i 74\% (CBOS 2019, 1). Interesująca jest też odpowiedź na pytanie: Jak Pan(i) sądzi, czy człowiekowi potrzebna jest rodzina, żeby rzeczywiście był szczęśliwy, czy raczej uważa Pan(i), że bez rodziny można żyć równie szczęśliwie? 87\% badanych wskazało, że do pełni szczęścia człowiek potrzebuje rodziny, a jedynie zdaniem 
pryzmat zapewnienia lepszej przyszłości kolejnemu pokoleniu odnaleźć można także w narracjach Polaków, którzy wyemigrowali wraz z rodzinami i postanowili zostać w Wielkiej Brytanii (White 2011). Zapewnienie lepszej przyszłości może być projektem wielopokoleniowym, gdy w opiekę nad wnukami zaangażowani są dziadkowie.

W rozważaniach nad mobilnością Polek, które mieszkają w Norwegii, warto przyjrzeć się, jaką rolę odgrywają w niej wyobrażenia i aspiracje, co to sposobu życia. W takim ujęciu ich migracja to nie tyle akt, co poszukiwanie, projekt, wolny wybór w dążeniu do pewnego sposobu życia, w którym decyzja o miejscu zamieszkania jest świadomą i intencjonalną odpowiedzią na pytanie, jak żyć. Styl życia w krajach skandynawskich niewątpliwie odróżnia się od tego, który dominuje w Polsce. W Norwegii łatwiej o uzyskanie równowagi pomiędzy życiem zawodowym a rodzinnym czy osobistym. Życie jest znacznie bardziej przewidywalne. To argumenty zachęcające do pozostania w tym kraju (Gmaj 2016, 2018a). Z drugiej jednak strony życie w Norwegii nie jest wolne od napięć związanych z różnicami kulturowymi i nieporozumieniami co do wartości i norm zachowań obowiązujących w polskim i norweskim społeczeństwie. Najbardziej wyrazistym tego przejawem jest niepokój rodziców przed zainteresowaniem ze strony norweskiej instytucji zajmującej się ochroną dzieci: Barnevernet. Jej interwencja może skończyć się odebraniem dzieci i przekazaniem ich rodzinie zastępczej z powodów dla biologicznych rodziców niezrozumiałych (Sokół-Rudowska 2013, Wærdahl 2015, Godzimirski i in. 2015).

Opowieści czterech Polek - trzydziestolatek, czterdziestolatki i pięćdziesięciolatki - wskazują, że analiza opierająca się na paradygmacie, w myśl którego migracja jest jedynie rezultatem skalkulowanego, racjonalnego wyboru odbywającego się w pojedynczym wycinku czasu, a sam migrant zredukowany jest do kalkulującej niezależnej jednostki stanowi duże uproszczenie. Zaprezentowany materiał potwierdza, że przyjęcie podejścia, zgodnie z którym migracje umiejscowione są w kontekście nakierowanych na przyszłość aspiracji, ale zarówno one same, jak i możliwości ich realizacji są częścią procesu rozciągającego się na przeszłość i teraźniejszość, pozwala lepiej zrozumieć migracje. Rzeczywistość migracyjna jest dynamiczna i wyłania się z wzajemnego oddziaływania indywidualnych podmiotów społecznych oraz czynników mikro- i makrostrukturalnych. Działania migrantek i migrantów są strukturalnie uwarunkowane, ale niezdeterminowane. Migrantki obdarzone indywidualną zdolnością do działania, korzystają lub nie wykorzystują możliwości, które przed nimi stoją. Negocjują działania swoje i innych, starają się adoptować do okoliczności bądź starają się twórczo zmieniać rzeczywistość, w której się znajdują. Wspierają je lub ograniczają w działaniach formalne i nieformalne okoliczności - różne regulacje

co dziewiątego respondenta bez rodziny można żyć równie szczęśliwie. Także wyniki badań dotyczących sensu życia potwierdzają mocną pozycję rodziny w systemie wartości Polaków (CBOS 1997, 2017). Dla ponad połowy Polaków - 54\% w 2017, 53\% w 1997 roku - sensem życia jest rodzina. W 2017 roku respondenci wskazali odpowiednio - jej dobro 48\%, harmonijne funkcjonowanie $6 \%$, poprawę sytuacji 


\section{SM̂PP}

prawne, osoby lub instytucje, które spotykają na swojej drodze. Kobiety są częścią układu i same stwarzają bądź blokują możliwości działania innych osób. Są wśród nich najbliżsi i przyjaciele, ale także inni ludzie, których napotykają na migracyjnych ścieżkach (pracownicy, osoby którym podnajmuje się mieszkanie czy świadczy inne usługi itd.). Ich pozycja w układzie nie jest stała, zmienia się.

Do migracji rozmówczynie przywiodły różnorodne pragnienia - chęć przeżycia przygody, miłości, lepszego/innego (niekoniecznie w wymiarze ekonomicznym, ale w nim także) życia dla siebie i bliskich, aspiracje zawodowe itp. Dla dwóch z nich Norwegia to pierwszy kraj poza Polską, w którym mieszkały, ale jedna z nich ma za sobą doświadczenie migracji wewnętrznej. Dla dwóch pozostałych kobiet to kolejne państwo. Analizując ich wypowiedzi widzimy, jak trening migracyjny podwyższa ich kapitał migracyjny, i jak z czasem stają się sprawniejsze w uruchamianiu potrzebnych umiejętności i pozyskiwaniu zasobów.

Wraz z czasem pragnienia i aspiracje rozmówczyń ewaluowały. W niestałych czasach drugiej czy późnej ponowoczesności planowanie dążeń życiowych wymaga wysiłku i wiąże się z elastycznością i adoptowaniem do zmieniających się okoliczności. Zważywszy na powyższe, pogodzić się musimy z tym, że także w kontekście analiz migracji coraz bardziej uderza nas ich nieprzewidywalność. To doświadczenie nie tylko samych migrantów (i badaczy), jest także udziałem ludzi, którzy nie uczestniczą w przemieszczeniach terytorialnych osobiście, ale ich świat przekształca się wraz z pojawieniem się przybyszy albo środków, przedmiotów i idei przyniesionych przez migrantów do społeczności, z których pochodzą.

Na różnych etapach życia, na różnych etapach migracyjnej drogi poziom autonomii jest wyższy lub niższy. Nawet w przypadku tych kobiet, które wykazały się wysokim poziomem autonomii podejmując decyzję o migracji, pobyt poza Polską może wiązać się z czasowym jej ograniczeniem, np. przez typ podejmowanej pracy i funkcjonowanie w nieformalnej strefie, problemy z uznaniem wykształcenia, czy niedostateczną znajomością języka norweskiego i realiów nowego kraju, brakiem fizycznej obecności rodziny, która pozostała w Polsce itd. Te ograniczenia mogą (ale nie muszą) przeminąć. Warto też zwrócić uwagę, że realizując własne pragnienia, migrantki mniej lub bardziej świadomie mogą się przyczyniać do ograniczania przynajmniej czasowej autonomii innych kobiet, czy to zatrudniając je w niesformalizowany sposób, czy też sprowadzając babcie do opieki nad wnukami i skazując je na poczucie wyobcowania poza Polską.

\section{Bibliografia}

Bakewell O. (2010), Some Reflections on Structure and Agency in Migration Theory, Journal of Ethnic and Migration Studies, 36 (10): Theories of Migration and Social Change, s. 1689-1708.

Baldassar L., Wilding R., Baldock C. (2007), Long-distance care-giving, transnational families and the provision of aged care, w: Paoletti I. (red.), Family Caregiving for Older Disabled People: Relational and Institutional Issues, New York: Nova Science, Chapter 10, s. 201-228. 
Bastia T. (2013), "I am going, with or without you": autonomy in Bolivian transnational migrations, Gender, Place \& Culture A Journal of Feminist Geography, 20 (2), s. 160-177.

Bauman Z. (2006), Płynna nowoczesność, przeł. T. Kunz, Kraków: Wydawnictwo Literackie.

Beck U., Beck-Gernsheim E. (2018), Miłość na odległość. Formy życia w epoce globalnej, przeł.

M. Sutowski, Warszawa: Wydawnictwo: Wydawnictwo Naukowe PWN.

Bell J., Bivand Erdal, M. (2015). Transnational family life among Polish migrants in Norway: Limited, but enduring transnational ties?, Studia Migracyjne - Przegląd Polonijny, Vol. 3, s. 77-98.

Benson M., O'Reilly K. (2016), From lifestyle migration to lifestyle in migration: Categories, concepts and ways of thinking, Migration Studies, Vol 4 (1), s, 20-37.

Berger P.L., Luckmann T. (2010), Społeczne tworzenie rzeczywistości. Traktat z socjologii wiedzy, przeł. J. Niżnik, Warszawa: Wydawnictwo Naukowe PWN.

Bielecka-Prus J., Czapka E i Kawczyńska-Butrym Z. (2018), The dilemmas of transnational care. The case of Polish immigrants in Norway, w: Slany, K., Pustulka, P., Guribye, E., Ślusarczyk, M. (red.), Transnational Polish families in Norway: Social capital, integration, institutions and care, Frankfurt am Main: New York: Peter Lang, s. 199-222.

Bjornholt M., Stefansen K. (2018), On the move: Transnational family practices among Polish parents working and caring for children in Norway, w: Slany, K., Pustulka, P., Guribye, E., Ślusarczyk, M. (red.), Transnational Polish families in Norway: Social capital, integration, institutions and care, Frankfurt am Main: New York: Peter Lang, s. 155-172.

Bourdieu P., Wacquant L. (2001), Zaproszenie do socjologii refleksyjnej, przeł. A. Sawisz, Warszawa: Oficyna Naukowa.

Carling J., Collins F. (2018), Aspiration, desire and drivers of migration, Journal of Ethnic and Migration Studies, Vol. 44 (6): Special Issue: Aspiration, Desire and the Drivers of Migration, s. 909-926.

CBOS (1997), Portret Polaka frasobliwego - opinie o sensie życia, wartościach życiowych i marzeniach. Komunikat z badań Centrum Badań Opinii Społeczne, Nr BS/58/58/97.

CBOS (2008), Nie ma jak rodzina. Komunikat z badań Centrum Badań Opinii Społeczne, $\mathrm{BS} / 40 / 2008$.

CBOS (2013), Rodzina - jej współczesne znaczenie i rozumienie. Komunikat z badań Centrum Badań Opinii Społecznej, BS/33/2013.

CBOS (2017), Sens życia -wczoraj i dziś. Komunikat z badań Centrum Badań Opinii Społecznej, $\mathrm{Nr}$ 41/2017.

CBOS (2019) Rodzina - jej znaczenie i rozumienie. Komunikat z badań Centrum Badań Opinii Społecznej, Nr 22/2019.

Collins F.L., (2018), Desire as a theory for migration studies: temporality, assemblage and becoming in the narratives of migrants, Journal of Ethnic and Migration Studies, Vol. 44 (6): Special Issue: Aspiration, Desire and the Drivers of Migration, s. 964-980.

Connell J. (2008), Niue: Embracing a Culture of Migration, Journal of Ethnic and Migration Studies, Vol. 34 (6), s. 1021-1040.

Deleuze G., Guattari F. (1983), A Thousand Plateaus: Capitalism and Schizophrenia, Minneapolis: University of Minnesota Press.

Donato K.M., Gabaccia D. (2015), Gender and International Migration, from the Slavery Era to the Global Age, New York: Russell Sage Foundation.

Erdal, M.B. (2014). Praca i rodzina: Rozważania o powrocie wśród Polaków mieszkających w Norwegii. Studia Migracyjne - Przegląd Polonijny, nr 2, s. 41-64. 


\section{SM̂PP}

Friberg J.H., R.K. Tronstad, i J.E. Dølvik. (2012), Central and Eastern European Labour Migration to Norway: Trends, Conditions and Challenges, w Free Movement of Workers and Labour Market Adjustment: Recent Experiences from OECD Countries and the European Union. OECD Publishing, s. 147-172.

Friberg J.H. (2010), Working conditions for Polish construction workers and domestic cleaners in Oslo: Segmentation, inclusion and the role of policy, w: R. Black, G. Engbersen, M. Okólski (red.), A continent moving west?: EU enlargement and labour migration from Central and Eastern Europe, Amsterdam: Amsterdam University Press, s. 23-50.

Giddens A. (2010), Nowoczesność i tożsamość. „Ja” i społeczeństwo w epoce późnej nowoczesności, przeł. A. Szulżycka, Warszawa: Wydawnictwo Naukowe PWN

Gmaj K. (2018 a), „Oswajanie” Norwegii: wzory osiedleńcze polskich migrantów w Norwegii, Studia Migracyjne - Przegląd Polonijny, nr 1, s. 163-188.

Gmaj K. (2018 b), Inspired by Thomas and Znaniecki: do we observe the formation of a new Polish-Norwegian society, Sociology Study, Vol. 8 no. 3, s. 103-111.

Gmaj K. (2016), Settling in Norway? The Case of Polish Migrants and Their Families, Myśl Ekonomiczna i Polityczna/The Economic and Political Thought, Vol. 2, s. 163-190.

Gmaj K. i Iglicka K. (2018), The Story of the Icy Paradise: Polish Migration to Norway after the EU Enlargement (2004) in the Light of Research and Statistical Data, CBU International Conference Proceedings, ISE Research Institute, vol. 6(0), s. 156-161.

Godzimirski J.M., Stormowska M., Dudzińska K. (2015), Nowe diaspory w Europie i zarządzanie migracją: Przypadek Polaków w Norwegii, Warszawa: Polski Instytut Spraw Międzynarodowych, Instytut Studiów Politycznych Polskiej Akademii Nauk, Norweski Instytut Spraw Międzynarodowych.

Hirschmann N.J. (2003), The Subject of Liberty Toward a Feminist Theory of Freedom, Princeton, NJ: Princeton University Press

Iglicka K., Gmaj K., Wierzejski A. (2018), Contextualizing Polish Migration to Norway in the light of theory, statistical data and research findings, w: Slany, K., Pustulka, P., Guribye, E., Ślusarczyk, M. (red.), Transnational Polish families in Norway: Social capital, integration, institutions and care. Frankfurt am Main: New York: Peter Lang, s. 43-70.

Kandel W., Massey D.S. (2002), The Culture of Mexican Migration: A Theoretical and Empirical Analysis, Social Forces, Vol 80 (3), s. 518-534.

Kaźmierska K. (1997), Wywiad narracyjny - technika i pojęcia analityczne, w: Czyżewski M., Piotrowski A., Rokuszewska-Pawełek A. (red.), Biografia a tożsamość narodowa, Łódź: Katedra Socjologii Kultury.

Konecki K. (2000), Studia z metodologii badań jakościowych. Teoria ugruntowana, Warszawa: Wydawnictwo Naukowe PWN.

Krzyżowski Ł. (2011), In the Trap of Intergenerational Solidarity: Family Care in Poland's Ageing Society, Polish Sociological Review Vol. 173(1), s. 55-78.

Krzyżowski Ł., Slany K., Ślusarczyk M. (2017), Care Issues in the Transnational Families. A Polish Research Review, Polish Sociological Review, Vol. 199 (3), s. 367-385.

Łukasiuk M. (2007), Obcy w mieście. Migracja do współczesnej Warszawy, Warszawa: Wydawnictwo Akademickie Żak.

Main I., Czerniejewska I. (2017), Post-accession Female Mobility between Poland and Norway. New Trends and New Ways of Thinking about Migration, Sprawy Narodowościowe, nr 49, s. $1-18$ 
Morawska E. (2001), Structuring Migration: The Case of Polish Income-Seeking Travelers to the West, Theory and Society, Vol. 30, No. 1, s. 47-80.

Müller M. (2015), Assemblages and Actor-networks: Rethinking Socio-material Power, Politics and Space, Geography Compass, Vol 9 (1), s. 27-41.

Napierała J. (2010), Sytuacja Polek na rynkach pracy w Danii i Norwegii w okresie poakcesyjnym, Studia Migracyjne - Przegląd Polonijny, nr 4, s. 55-78.

Nare J. (2004), Agency as capabilities: Ukrainian women's narratives of social change and mobility, Women's Studies International Forum, Vol. 47, Part B, s. 223-231.

Nesteruk O., Marks L. (2009). Grandparents Across the Ocean: Eastern European Immigrants' Struggle to Maintain Intergenerational Relationships, Journal of Comparative Family Studies, Vol. 40(1), s. 77-95.

Przybyłowska I. (1978), Wywiad swobodny ze standaryzowaną listą poszukiwanych informacji i możliwości jego zastosowania w badaniach socjologicznych, Przegląd Socjologiczny 30, s. $53-68$.

Quaglia R.J., Cobb C.D. (1996), Toward a Theory of Student Aspirations, Journal of Research in Rural Education, Vol. 12, No. 3, s. 127-132.

Riemsdijk M. van. (2008). Immigration, belonging and the politics of difference: Narratives of Polish nurses in Norway. PhD dissertation. Department of Geography. Ann Arbor: University of Colorado, https://search.proquest.com/docview/304677484?pq-origsite=gscholar, [data dostępu: 30.03.2018].

Radziwinowiczówna A., Rosińska A., Kloc-Nowak W. (2018), Ethnomorality of Care. Migrants and their Aging Parents, London: Routledge.

Romaniszyn K. (2003), Kulturowe implikacje międzynarodowych migracji, Lublin: Instytut Badań nad Polonią i Duszpasterstwem Polonijnym KUL.

Sassen, S. (2005), The Global City: Introducing a Concept, Brown Journal of World Affairs, Vol. 11(2), s. 27-43.

Sen A. (1993), Capability and Well-Being, w: Nussbaum M., Sen A. (red.), The Quality of Life. Oxford: Clarendon Press.

Slany K., Kontos M., Liapi M (red.) (2010), Women in New Migrations. Current Debates in European Societies, Kraków: Wydawnictwo Uniwersytetu Jagiellońskiego.

Statistics Norway, https://www.ssb.no/en/ [data dostępu: 30.03.2019].

Sokót-Rudowska M. (2013), Us among them: A study of the contemporary Polish emigration to Norway, Studia Humanistyczne AGH , Tom12/1, s. 9-24.

Steinkellner A. (2015), Befolkningens utdanningsnivå og arbeidsmarkedsstatus (Population and Labor Market Structure). https://www.ssb.no/ utdanning/artikler-og-publikasjoner/_attachment/221318? ts=14c123524d8, [data dostępu: 30.03.2018].

Syed A. (2007), 'Go West Young Man': The Culture of Migration among Muslims in Hyderabad, India, Journal of Ethnic and Migration Studies, Vol. 33 (1), s. 37-58.

Ślusarczyk M., Pustułka P. (2015), Transnational Polish Families in Norway. The Entanglements between Migration Trajectory and Labor. (WP2 Working Paper 1) http://www.transfam. socjologia.uj.edu.pl/documents/32445283/0fffac5e-2e7f-4923-a23c-6e5e532a6d5e, [data dostępu: 30.03.2018].

Titkow A. (2012), Figura Matki Polski. Próba demitologizacji, w: Pożegnanie z Matką Polką? Dyskursy, praktyki i reprezentacje macierzyństwa we współczesnej Polsce, (red.) Hryciuk R.E., Korolczuk E., Warszawa: Wydawnictwo Uniwersytetu Warszawskiego, s. 27-48. 
Waerdahl R. (2015), Integration and re-integration of Polish children in school: Part 1. Inclusion of Polish children in Norwegian schools (WP7 Working Report) http://www.transfam.socjologia. uj.edu.pl/documents/32445283/cde1 c85c-7786-4d50-9e3a-8c5a16ef0559, [data dostępu: 30.03.2018].

Wengraf T. (2001), Qualitative Research Interviewing. Biographic Narrative and Semi-Structured methods, London: Sage Publications.

White A. (2011), Polish Families and Migration since EU accession, Bristol: The Policy Press.

Vertovec S. (2012), Transnarodowość, przeł. I. Kabłon, Kraków: Wydawnictwo Uniwersytetu Jagiellońskiego. 